\title{
Exploring Students' Motivation and Vocabulary Achievement through Labeling Method
}

\author{
Erwin Kainta $^{1}$ \\ Universitas Pattimura, \\ erwino.kainta@gmail.com \\ Jerry Elfindo Rombot ${ }^{2}$ \\ Universitas Pattimura \\ elfindorombotjerry@gmail.com
}

\begin{abstract}
Motivation provides energies for students to decide efforts and they pursue it hardly. It is important to build students' motivation in learning English. Researcher's preliminary study toward the fourth grade of MIS Azzikir Kalialia in February 2019 indicated students' motivation was in the low category, while the result of the pre-test showed $35 \%$ of students did not achieve success standard in learning vocabulary. The objectives of the study is to explore how students are motivated by using labelling method and to improve students' vocabulary achievement by using labelling method. The number of the subject is 20 students. The instruments are the test, questionnaire, and observation under the Classroom Action Research method. After treatment, the questionnaire indicates students' motivation in high motivation and whole students achieve the standard of vocabulary achievement. Therefore, the labelling method promotes a way of English language teaching to build students' motivation and to improve vocabulary achievement in elementary grade.
\end{abstract}

ARTICLE HISTORY

Received 3 November 2019

Accepted 27 February 2020

\section{KEYWORDS}

Labelling Method; Students' Motivation and Vocabulary Achievement

\section{Introduction}

Vocabulary is an essential element of language is needed to be learned. The learners use vocabulary to convey their point of view when they speak or write something. They also recognize vocabulary to find out the meaning of sentences or utterances that they read or hear. Umar \& Irmayanti (2017: 153) state that "through vocabulary, we can make some sentences, understand the passage and also express our ideas effectively and efficiently".Vocabulary introduces how language is arranged word by word to create sentences or utterances meaningful. Moghadam, Zainal, \& Ghaderpour (2012: 1) state "vocabulary learning is dominant in language acquisition, whether the language is a second or a foreign language, and crucial to the learners' overall language acquisition". 
In vocabulary learning, motivation plays an important role for young students. Nunan (2003) in Fitriana, Nurkamto, \& Pudjobroto, (2012: 2) states that "motivation and learning attitude are important predictors of achievement". Slavin in Moya (2013) adds that "students who are highly motivated to learn something are more likely than others to consciously plan their learning, to carry out learning plan and to retain the information they obtain". The ideas mean that motivation provides energy for students to decide an effort, to pursue it hard and to connect their feeling to the activity. Iksan \& Dirham (2018: 118-119) state that "only motivations that are significantly influencing the students' English achievement". However, motivation has a crucial function to increase young learners' vocabulary achievement.

Young learners are better in the real context of the situation when they learn the language. Thornburry (2002: 18) explains that "in learning first language the first words that children learn are typically those used for labeling - that is mapping words on to concept". The concept introduces how children compare between a word and an object to understand the word in their environment, it creates conceptual knowledge for those words encode. However, foreign language learners already have their first language. Therefore, the labeling concept creates a language learning environment for the young learner.

Thornburry (2002: 18) states that "the different effect of labeling concept happens toward second and foreign language learner". Usually, foreign language learners translate words into their mother tongue to find out equivalent words between first language and the target language. However, the Labelling method adopts the labeling concept for vocabulary teaching. The method builds students' understanding about vocabulary by using concrete objects around them.

Steinbrecht \& Strausfeld (2012: 77) argue that "teachers can only hope to facilitate the process of labeling method, and the learners have to do on their own". Steinbrecht \& Strausfeld (2012: 77) add that "a new word has to be matched and integrated into the existing knowledge store, its meaning is negotiated in discourse and recreated in the mind by elaborate acts of relating and matching different kinds of knowledge". The labeling method is a way to introduce the vocabulary by matching the word and the referent of word in same time. The referent could be observable object or activity by students, while the word is integrated as label for the referent itself.

The method offers concrete referents for students to learn vocabulary, and then it encourages students to produce vocabulary at the same time. Further, the labeling method designs students' conceptual knowledge about vocabulary based on concrete referent. So, young students can easily recognize the meaning of new words with real referent by using the labeling method. It happens because they produce the vocabulary when they are observing the referent of vocabulary directly.

The researcher did a preliminary study toward the fourth grade of MIS Azzikir Kalialia in February 2019, the observation sheet of the study indicated that students' 
motivation had not arisen yet. While the result of the pre-test showed that 7 students $(35 \%)$ out of 20 students $(100 \%)$ did not achieve the indicator of success in vocabulary learning yet. This study applies the labeling method to raise students' motivation and to improve their vocabulary achievement at the fourth grade of the elementary school in 2019.

The significance of the study is: first, to build students' motivation in learning English vocabulary since students are starting to learn English. For elementary students, the class was divided into two levels. Low class starts from the first grade to the third grade and the high class begins with fourth grade to sixth grade. English subjects will be taught in the fourth grade. Based on some weaknesses in the previous study, the researcher thinks that it is a good idea if he digs out deeply about students' motivation at the fourth-grade level. In this research, he uses classroom action research under the quantitative-qualitative approach.

Second, based on the latest previous study conducted by Moya (2013) entitled Enhancing motivation in vocabulary learning: a Cognitive approach, she concluded there were two differences students' motivation between class A and class B in vocabulary learning based on the research. In conducting the study, she analyzed the result of a vocabulary test. It is reported that the students who had high motivation obtained better results and they acquired the vocabulary with ease. It can be concluded there was a relationship between motivation and vocabulary achievement.

Based on the gap in his preliminary study, the researcher focuses on exploring students' motivation and vocabulary achievement. The research questions for this study are: 1) how can students be motivated in mastering vocabulary through the use of labeling method at the fourth grade of MIS Azzikir Kalialia? 2) How can a student's vocabulary achievement be improved through the use of labeling method?

\section{Literature Review}

In learning the first language for young learners, the first step is typically labeling the concrete thing with a certain name. The step builds a concept to create mapping words for them. Thornburry (2002: 18) indicates that "knowing a word is one thing". The idea implies that every word refers to something. The simple concept is used by young learners when they learn their first language. The concept of labeling real object supports students to understand word by word. Thornburry (2002: 18) state "In learning their first language the first words that children learn are typically those used for labeling- that is mapping words on to concepts - so that the concept"

In the teaching method, the concrete thing supports the teacher to introduce the meaning of word directly for young students (Kainta, 2016: 39). When a teacher states a new word and then shows the object, students' attention will be focusing on the object. They create a relation between the vocabulary and the object. In this situation, students are built the concept of words toward the object and then limit the 
meaning of word base on discourse. Further, it is a good progression for young learners to start vocabulary learning for young learners.

The concrete thing is the real object that can be seen by the students. Allen (1983: 9) states that 'the concrete thing comes to the learners' attention as part of an experience that special importance for young learners". The idea implies that the concrete thing attracts students' attention to focus when they learn vocabulary. Allen (1983: 7) adds that "one reason is that the meanings can easily be made clear". The labeling method limits the concept of the word based on students' sense toward the object. It helps them to understand the words easily.

Thornburry (2002: 76) offers two procedures to teach vocabulary as follows:

1. The referent of vocabulary first, then the vocabulary

A teacher can hold up or point the object, and then say the name of the object. Example: a teacher holds a book and says "this is a book". The students are asked to say or repeat the word several times until they can say it in the correct pronunciation. The students also can point to the concrete thing directly Thornburry (2002: 7) states that "presenting meaning first creates a need for the form, opening the appropriate mental 'files' and making the presentation both more memorable".

2. The vocabulary first, then referent of vocabulary

It relates to the means of presentation-whether to present through; translation, real things, pictures, actions or gesture, definition, situations. Example of the procedure of the sense; a teacher says the word and asks the students to repeat the word several times. A teacher writes the word on the whiteboard and asks the students to spell it. When they can spell it correctly, then the teacher shows the concrete thing. It is used to create the true form of the word both written and spoken.

\section{Methodology}

Classroom Action Research was used under the quantitative-qualitative approach in conducting this study. Syae Purohman (2011: 1) states that "Classroom Action Research is an alternative research application that easily conducted during teaching and learning processes. Classroom Action Research sharpened teachers' skills in teaching with simple methodological research applications. The researcher pushed to make notes about classroom activities, doing the action, observe and make reflections".

Kemis and Taggart (1998) in Wass (2016: 18) states that there were four steps to do classroom action research; (1) Planning the action, (2) Implementing the action, (3) Observing the action and (4) Making the analysis and reflecting the action. The subject of the research is all fourth-grade students MIS Azzikir Kalialia who registered in the school year 2018/2019, they are 20 students. The school located in 
Baubau city southeast Sulawesi. In this research, the researcher acted as a teacher and a teacher of school acted as an observer. The research was held in February-May 2019.

There were three instruments as a technique to collect data. 1) Test was used to measure students' vocabulary achievement during research. Each sheet of the test consisted of 20 questions. 2) The questionnaire was used to measure students' motivation through they were learning English vocabulary. The questionnaire consisted of 20 statements. Likert scale was applied for questionnaire with five optional answers, those were strongly disagree, disagree, neutral, agree and strongly agree. 3) Observation was used to support the data test and data questionnaire in the research.

The indicator of success was standard to measure whether the research was successful or failed in the classroom action research. It would be measured in each cycle. The criterion was $100 \%$ of students should obtain a good score in vocabulary achievement. On the other side, they ought to get a good motivation criterion during vocabulary learning in the English class.

To analyze the data from instruments, the score of students' motivation and their vocabulary achievement were calculated by using Microsoft excel 2007. The data resulted through that calculation was converted by the formula on the descriptive statistic. Creswell (2012: 182) states that descriptive statistic is required to indicate general tendency (mean, mode and median). Besides that, the descriptive statistic displayed the minimum and maximum scores. There were two kinds of data descriptive as followings;

The questionnaire applied a Likert scale with five options. Losby \& Wetmore (2012: 4) state that the "Likert scale is an ordered scale from which respondents choose one option that best aligns with their view". The scale typical was five optional statements, those were: a point for "Strongly disagree", two points for "Disagree", three points for "Neutral", four points for "Agree" and five points for "Strongly Agree". The mean score students' motivation of vocabulary learning categorized into five categorizations range, those were: 20-40 points were "Very Low", 41-53 points were "Low", 54-67 points were "Moderate", 68-80 points were "High", 81-100 points were "Very High

To determine students' vocabulary achievement, the researcher gave 5 points for the right answer and no point for the wrong answer for the score range 0-100 out of 20 exercises. Thornburry (2002: 138) states that a teacher can assess students' number of words by asking them to tick the words they are familiar with. He adds that the students have two familiar choices; I know the word and I don't know the word.

Direktorat Jendral Pendidikan Dasar dan Menengah (2015: 62) categorized four ranges of students' vocabulary achievements, those were 86-100 were very good criteria or "A" Scoring in letter, 71-85 were good or "B" Scoring in letter, 56-70 were 
Moderate or "C" scoring in letter and least than 56 were Low or "D" scoring in letter. The researcher adopted the criteria above to determine students' vocabulary achievement.

\section{Finding}

\section{The cycle of Classroom Action Research}

1. Planning the Action

First, the researcher and the English teacher of the school collaborated to design six lesson plans for six meetings that consisted of two chapters (Body and face" and "put on your cap, please). The vocabularies consisted of 25 nouns, 20 verbs, 22 adjectives, and 14 pronouns, then the researcher distributed the vocabularies in each meeting. On another side, they involved part of bodies as media of teaching to support the researcher when he applied the labeling method.

Second, they designed the sheet of posttest that consisted of twenty questions. The posttest involved two chapters about the vocabularies that the students would learn in the class. The vocabularies consisted of nouns, verbs, adjectives, and pronouns in the sheet of the posttest. Third, they designed the observation sheet to describe students' motivation during vocabulary learning through the use of labeling method. Naiman et al (1978) in Waas (2016: 18) states that criteria of students motivated as followings;

a. Positive task-oriented, the student who is motivated in learning is willing to tackle tasks and challenges and has confidence in his or her success.

b. Ego-involvement, the student finds it important to succeed in learning to maintain and promote his or her positive self-image.

c. Need for achievement, the student needs to achieve, to overcome difficulties and to succeed in what he/she sets out to do.

d. High Aspiration, Student is ambitious, and he goes for demanding challenging, high proficiency and top grades.

e. Goal Orientation, the student is very aware of the goals of learning or specific learning activities and directs his or her effort towards achieving them.

f. Perseverance, student consistently invests the high level of effort in learning and is not discouraged by setbacks or apparent lack of progress.

g. Tolerance of ambiguity, the student is not disturbed by the situation involving a temporary lack of understanding or confusion; he or she can live with this patiently, in the confidence the understanding will come later.

The observation sheet and questionnaire sheet involved seven points above.

2. Implementing the action 
The first meeting held at 09.00-09.45 am on March $4^{\text {th, }}$ 2019. The researcher taught 12 new vocabularies that consisted of 6 nouns and 6 verbs. He taught the meaning of the word first, and then he taught the form of the word to apply the labeling method. The researcher taught 13 new vocabularies that consisted of 4 nouns and 9 adjectives in the second meeting. He taught a form of words first then the meaning of words. It was held at 09.45.00-10.30 am on

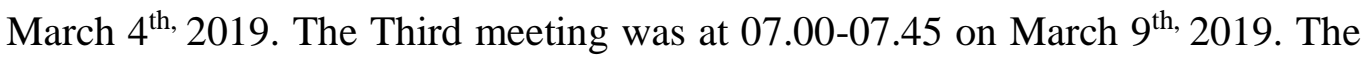
researcher taught 14 new vocabularies that consisted of 2 nouns, 6 pronouns, 2 adjectives, and 4 verbs. The researcher stimulated the meaning by using media to find out the meaning of the word during his teaching process. The first till the third meeting was taught under chapter body and face.

The fourth until the sixth meeting was applied under the chapter "put on your cap please". The researcher showed the real object in the class and out of the class like buildings as the media of teaching to support the teaching method. He applied the labeling method by introducing real objects (the meaning of the word) first, then form of vocabulary for the meetings. The researcher taught 14 new vocabularies that consisted of 3 nouns, 3 verbs, 2 adjectives and 6 pronouns in the fourth meeting. It was held at $07.45-08.30$ on March $9^{\text {th }}, 2019$. The fifth meeting was held at $09.00-09.45$ on March $11^{\text {st }} 2019$. A researcher taught 14 new vocabularies that consisted of 7 nouns and 7 verbs. The sixth meeting was held at 09.45-10.30 am on March $11^{\text {st }} 2019$. The researcher taught 14 new vocabularies that consisted of 3 nouns, 9 adjectives, and 2 pronouns.

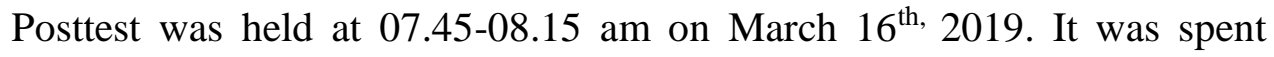
about 30 minutes for students to complete their posttest sheets. A researcher was helped by the teacher to supervise the students in the posttest. But during teaching, the teacher completed the observation sheet based on the fact in the

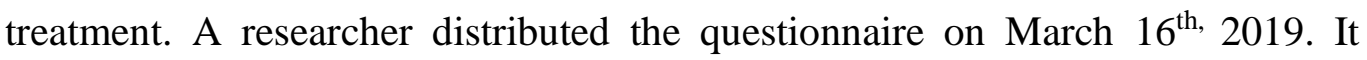
spent 30 minutes that started at $08.30 \mathrm{am}$. The researcher and the teacher guided the students to fill the sheet of the questionnaire.

3. Evaluation

The observation sheet in the first cycle described that students had the motivation to learn vocabulary by using the labeling method. The sheet showed that students were active to participate in mastering vocabularies during learning. They said vocabularies loudly without fear of wrong. They accepted the correction from their friends and researcher. It was an interested class for students to arise their motivation in learning vocabulary.

The students maintained their self-confidence which described their motivation to master vocabulary. Most of them dared to raise their hands and answered the question individually. Each student hoped for the researcher to 
point him/her to answer the question. They promoted themselves to show that they have mastered the vocabularies that were taught by the researcher.

Students were ambitious, they went for demanding to master more new vocabularies. The teacher saw that students asked about vocabularies that a researcher not taught yet in the class such as Pesawat, Kapal Laut, Helikopter, etc. A teacher noted that students had a strong motivation to learn more vocabulary. They tried to use the vocabularies that they have memorized in the simple context of their environment, it meant they had goal orientation when they learned vocabulary because they applied the vocabulary to build communication among them.

Further, the observation sheet showed that students followed the instruction of the researcher with good attention. They wrote the vocabulary in their notebook tidily. They considered between writing and reading vocabulary carefully. These attitudes described the arising of students' motivation. So, the teacher as an observer assumed that students were motivated through the labeling method in vocabulary learning.

The score of the questionnaire that measured students' motivation in learning vocabulary could be seen in the table below.

Table 1. The Score of Students' Motivation by Indicatory

\begin{tabular}{llllll}
\hline No. & Indicator & Total Item & Item & $\begin{array}{l}\text { Total } \\
\text { Score }\end{array}$ & $\begin{array}{l}\text { Mean } \\
\text { Score }\end{array}$ \\
\hline 1 & Positive task-oriented & 3 & $1,8,15$ & 248 & 82.7 \\
\hline 2 & Ego-involvement & 3 & $2,9,16$ & 244 & 81.3 \\
\hline 3 & Need for achievement & 3 & $3,10,17$ & 243 & 81 \\
\hline 4 & High Aspiration & 3 & $4,11,18$ & 244 & 81.3 \\
\hline 5 & Goal Orientation & 3 & $5,12,19$ & 240 & 80 \\
\hline 6 & Perseverance & 2 & 6,13 & 163 & 54.3 \\
\hline 7 & Tolerance of ambiguity & 3 & $7,14,20$ & 239 & 79.7 \\
\hline
\end{tabular}

Based on the table above, it could be seen the first indicator was positive task-oriented has 3 items, the score was 248 with 82.7 of the mean score. The second indicator was Ego-involvement has 3 items, the score was 244 with the mean score 81.3. The third indicator need for achievement has 3 items, the score was 243 with the mean score 81 . The fourth indicator was high aspiration has 3 items, the score was 244 with the mean score 81.3 . The fifth indicator was goal orientation has 3 items, the score was 240 with the mean score 80 . Whereas the sixth indicator was perseverance has 2 items and the score was 163 with the mean score 54.3. The last indicator was tolerance of ambiguity has 3 items, the score was 240 with the mean score 80 . 
From the data above, a researcher determined the mean score of students' motivation displayed in the table follows:

Table 2. The Score of Students' Motivation

\begin{tabular}{lll}
\hline \multirow{2}{*}{ Students' motivation in vocabulary learning. } & Total & Mean Score \\
\cline { 2 - 3 } & 1621 & 81.05 \\
\hline
\end{tabular}

Based on the table, the total score of the questionnaire for students' motivation was 1621 which the mean score was 81.05. It indicated students' motivation in learning vocabulary by using the labeling method was very good.

On the other side, the result of the students' vocabulary achievement was presented as follows able:

Table 3. Students' Vocabulary Achievement Category in Posttest.

\begin{tabular}{llll}
\hline Criteria & Scoring in Letter & Frequency & Percentage \\
\hline Very Good & A & 11 & $55 \%$ \\
\hline Good & B & 9 & $45 \%$ \\
\hline Moderate & C & - & - \\
\hline Low & D & - & - \\
\hline Percentage of students achieved the indicator of success & $100 \%$ \\
\hline
\end{tabular}

The table showed that 9 students $(45 \%)$ were in the "Good" or "B" scoring letter. Whereas 11 students (55\%) found "very good" criteria with " $A$ " scoring letter. While the table indicated that 20 students (100\%) achieved the indicator of success. It could be concluded that the students' vocabulary achievement in the posttest was in a very good category because the category was achieved by most students.

A researcher put the result of posttest to dig out deeply the strength and weakness of students' vocabulary achievement as presented as follows;

Table 4. True and False of Students' Vocabulary Achievement in Posttest.

\begin{tabular}{lllllllll}
\hline & \multicolumn{2}{l}{ 20 Questions (100\%) of Posttest in Second Cycle } \\
\cline { 2 - 9 } & 5 Nouns $(25 \%)$ & 5 Verbs $(25 \%)$ & $\begin{array}{l}\text { 5 Adjectives } \\
(25 \%)\end{array}$ & \multicolumn{2}{l}{$\begin{array}{l}\text { 5 Pronouns } \\
(25 \%)\end{array}$} \\
\cline { 2 - 9 } & True & False & True & False & True & False & True & False \\
\hline 20 Students & 90 & 10 & 83 & 17 & 88 & 12 & 89 & 11 \\
\hline Mean Score & 18 & 2 & 16.6 & 3.4 & 17.6 & 2.4 & 17.8 & 2.2 \\
\hline
\end{tabular}

The table showed that the test consisted of twenty questions, then the questions divided into four types of vocabulary questions those were; five questions for the noun, five questions for the verb, five questions for adjective and five questions for the pronoun. The high mean score that achieved by 
students was noun vocabulary, it was indicated by students' mean score of true was 17 . While, the mean score of true for verb questions were 16.6, for adjective questions were 17.6 for pronouns were 17.8. Further, the score was in a high score.

4. Reflection

According to the description of evaluation, a researcher and a teacher concluded three points about the cycle of classroom action research. First; they agreed that the labeling method arose students' motivation in the vocabulary learning process. This could be proven by the description of the observation sheet. The observation sheet was supported by data of the questionnaire that measured students' motivation in learning vocabulary. Students' mean score in the questionnaire was 87.5 , it indicated students' motivation was in the very good category.

Second; they agreed that the labeling method improved students' vocabulary achievement. The figure bellow showed students' vocabulary achievement of success and failure for each test of research.

Figure 1. Success and Failure Percentage of Students' Vocabulary Achievement

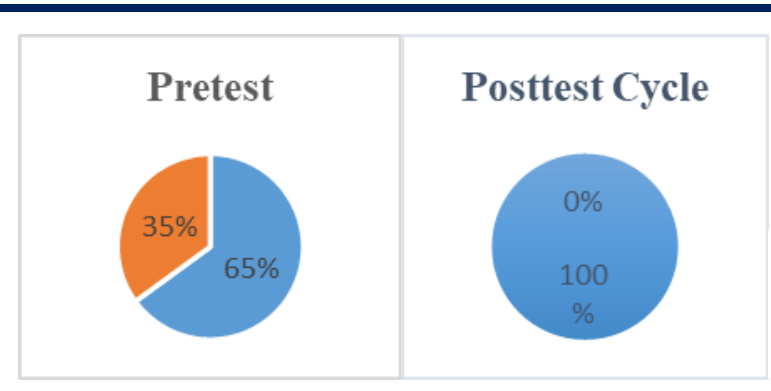

- Achieved indicator of success

- Not achieved indicator of

The figure showed that $65 \%$ of students achieved the indicator of success and $35 \%$ of students not achieved the indicator of success yet in the pretest. Further, 20 students $(100 \%)$ achieved the indicator of success in the posttest of the second cycle.

\section{Discussion}

The first principle of research was to describe the arising of students' motivation in learning vocabulary by using the labeling method. The researcher considered the motivational condition for students to learn vocabulary through the labeling method. Dörnyei, (2001: 31) suggested three points to create basic motivational conditions, those were; the first was appropriate teacher behavior and good relationship with students, the second was a pleasant and supportive classroom atmosphere and the third was a cohesive learner group with appropriate group norms. The researcher involved the points when he applied the method.

Steinbrecht \& Strausfeld (2012: 77) argue that "teachers can only hope to 
facilitate the process of labeling method, and the learners have to do on their own". Steinbrecht \& Strausfeld (2012: 77) add that "a new word has to be matched and integrated into the existing knowledge store, its meaning is negotiated in discourse and recreated in the mind by elaborate acts of relating and matching different kinds of knowledge". Labelling method is a way to introduce vocabulary by matching the word and the referent of word in the same time.

The researcher had to be close to students to arise students' motivation. While the method allowed the researcher to be close to students. The researcher showed concrete referent while the students produced the vocabulary at the same time. He did a demonstration to show the referent of the verb word, while his students did the demonstration and produce the vocabulary at the same time. The situation created a good relationship between the researcher and students. The researcher gave the real example of using vocabulary to build his students' motivation to use vocabulary in the school.

The researcher gave attention to students to learn vocabulary in practice way. He controlled the whole of students when he applied the labeling method. He repeated the example of pronunciation for many times until his students produced the correct one of vocabulary. He asked about the difficulty of each student and then he gave the solution for the students. He gave the same chance for whole students in the class. The attitudes of the researcher created a good relationship with his students.

The labeling method encouraged students to learn vocabulary in a natural situation. The researcher offers vocabularies that related to student environments such as parts of the body, names of buildings around them and some verbs that usually they did. The researcher focused on the vocabulary that easy to be understood by young students and he avoided the vocabulary that implied the abstract referent such as love and belief. However, the method created a supportive classroom atmosphere for students to master a foreign language. Ali (2006: 64) stated that "The new word is taught by the direct association of the word and its referent. This method is best applicable in this case of words referring to concrete thing existent in the classroom itself".

The supportive classroom atmosphere encouraged students' motivation to learn. When a researcher thought that the students have mastered the vocabulary, he created some groups for students to learn vocabulary together. A group consisted of three students. Each student had different roles; the first student pointed or acted any activity, the second student guise and then produced the vocabulary that the first student meant. The third student wrote the vocabulary that was mentioned by the second student. The students exchanged their roles with each other after three vocabularies. They did it with pleasure. Further, these activities created the basic motivational conditional of learning vocabulary through the use of the labeling method.

The observation sheet explained each student was active to participate in 
mastering vocabularies that were taught. Dörnyei (2001: 7) states that "motivation explains why people decide to do something, how hard they are going to pursue it and how long they are willing to sustain the activity". The students produced vocabulary loudly without fear of making mistakes. They accepted the correction from their friends and researcher. They enjoyed learning vocabulary through the labeling method. Gollwitzer \& Oettineen (2001: 1-3) state that "motivation has the function to keep basic students' needs and their action control".

Students followed the instruction of the teacher with good attention. They wrote the vocabulary in their notebook tidily. They also considered writing and reading vocabulary carefully. Slavin in Fitriana, Nurkamto, \& Pudjobroto (2012: 13) states that "motivation is important not only in getting students to engage in academic activities but also in determining how much students will learn from the activities they perform or from information to which they exposed". The Description of the observation sheet was supported by students' mean scores in the questionnaire. The questionnaire was used to measure students' motivation. The questionnaire's mean score was 81.05, it indicated students' motivation was in the very good category. Further, both observation sheets and questionnaires indicated the arising of students' motivation by using the labeling method for the fourth grade of MIS Azzikir Kalialia.

The second principle of research was the improvement of student's vocabulary achievement by using the labeling method. In applying the labeling method, the researcher did some ways to teach vocabulary. When he taught noun vocabularies he involved the real object as the media of teaching. He showed or pointed to the media while he produced the vocabularies, then the students understood the meaning of vocabularies directly. The researcher asked them to point or to touch the media while they were producing the vocabularies together. The situation stimulated students' sense to understand the vocabulary and referent of vocabulary itself. Marguerite Koons (2013: 34) states that "concrete thing is easier to understand than abstract one".

The researcher acted some actions to stimulate students' attention and their idea to judge the meaning of vocabulary that related to the adjective. As known that adjectives qualified a noun or pronoun, so some adjectives such as the colors could be seen by students directly. But some of the adjectives couldn't be seen such as expensive or cheap. In this situation, a teacher did any activity to stimulate students' thinking about vocabulary. He acted like a buyer when asked the cost of something, then he showed anybody languages that implied the referent of vocabularies.

The labeling method created an English environment suitable for young students to learn vocabulary in their environment. Zohrabi (2011: 145) argues that the teacher has to consider teaching materials as concrete manifestations of methods. While Meiliana (2016: 40) explains that the labeling method involves the abstract concept of the word into the concrete thing. It was easy for learners to remember 
because the referent of the word was easier to be drawn in their brains. Meanwhile, learners understood the new abstract word to the concrete one by using their sense (at least sight and hearing) by looking for the referent that word has sound alike. So, when learners learn new English vocabulary through the labelling method, they associate between vocabulary and the referent of vocabulary directly.

Everything around them that happened around them could be media to support them in mastering vocabulary. Allen (1983: 12) states that "a teacher can provide the showing meanings of words". In the learning process, the students paid attention to what researcher showed or pointed toward any real object and they heard the name object itself in English, then the researcher asked them to produce what they heard for several times while they were pointing or acting like researcher did until their pronunciations were true. This situation stimulated them to master the vocabulary without translating it into their mother tongue.

When the students could be produced vocabularies and understood its meaning, the researcher wrote the vocabularies one by one on the whiteboard while students were producing it together. Norbert (2000: 57) explained that "the teacher can give stress and other phonological information by pronouncing a word in isolation". The researcher realized that words can sound somewhat different when spoken together. So, a researcher asked them to produce the vocabulary several times until their pronunciations were true and then they wrote down the vocabularies in their notebook.

When the whole of students could produce the vocabularies truly, the researcher asked one by one of them regularly to come in front of the class and point three objects and acted three activities, while the other students produced the word in English loudly to determine what their friend meant. The situation trained their sight and hearing to master the vocabulary. Allen (1983: 8) states that "at least those two senses (sight and hearing) are working together to focus the learners' attention. In this situation, there was a student had a job to write the vocabularies on the whiteboard. A researcher gave the stress on mastering vocabulary on writing too because he considered that the test would be in the vocabulary writing test.

The result of the test showed the improvement of student's vocabulary achievement. In the pretest, there were 13 students (65\%) achieved the indicator of success, while 7 students (35\%) did not achieve the indicator of success yet. However, 20 students $(100 \%)$ achieved the indicator of success in the posttest of the first cycle. These score descriptions of tests showed the improvement of students' vocabulary achievement through using the labeling method at fourth grade MIS Azzikir Kalialia. 


\section{Conclusion}

It is important to build students' motivation in learning English since they start to learn it. Dörnyei (2001: 1) states that "motivation' is an abstract, hypothetical concept used to explain why learners think and behave as they do". Motivation provides energies for students to decide efforts and they pursue it hardly. For elementary students, the class was divided into two levels. Low class starts from the first grade to the third grade and the high class begins with fourth grade to sixth grade. English subjects will be taught in the fourth grade. So, the study is important to conduct in the fourth grade in order to build students' motivation in learning English.

The young students get an easy way to master vocabulary than grammar when they learn a foreign language. Fourth-grade students are indicated as young students, so they tend to learn vocabulary. Vocabulary conveys meaning in a particular language. Thornbury (2002: 13) states that "learners will see most improvement if they learn words". The statement indicates that vocabulary has a crucial role for students to learn a foreign language. Further, it is a good way for young students to start to learn a foreign language through vocabulary learning in a real context situation.

This study finds out the advantages and disadvantages of the labeling method. Based on research, the labeling method could be a way to build young students' motivation and to improve their vocabulary achievement at the elementary level. The labeling method is a way to introduce the vocabulary by matching the word and the referent of the word at the same time. The referent could be an observable object by the students, while the word is integrated as a label for the referent itself. The method offers a practice way for students to use English in school so that the method could be used as a way to raise students' motivation and to improve their vocabulary achievement.

As every research has a limitation, this study also is not an expectation. The labeling method limits vocabularies in the students' environment, many abstract vocabularies couldn't be interpreted directly, and the method couldn't reach vocabularies out of students' sense. However, this research was conducted in an elementary school with twenty students as an object of study. Other researchers can dig out deeply about research to find out better results. 


\section{References}

Ali, A. M. (2006). Methods of Teaching English (2006th ed.). Yordania.

Allen, V. F. (1983). Techniques in Teaching Vocabulary (N. C. Russel \& R. E. William, Eds.). Oxford University Press.

Creswell, J. W. (2012). Educational Research: Planing, Conducting and Evaluating Qualitative and Quantitative Research. Boston: Pearson Educational Inc.

Direktorat Jenderal Pendidikan Dasar dan Menengah. (2015). Buku Panduan Penilaian untuk Sekolah Menengah pertama (SMP). Jakarta.

Dörnyei, Z. (2001). Motivational Strategies in the Language Classroom. In D. Zoltan (Ed.), United States of America by Cambridge University Press (Vol. 61). https://doi.org/10.1353/cml.2005.0007

Fitriana, F. N., Nurkamto, J., \& Pudjobroto, H. (2012). A Correlation between Learning Motivation and Vocabulary Mastery and Reading Competence. Pusat Dokementasi Dan Informasi IImiah UNS, 1, 1-17. Retrieved from https://eprints.uns.ac.id/id/eprint/1278

Gollwitzer, P. M., \& Oettineen, G. (2001). Motivation: History of the Concept. In International Encyclopedia of the social and behavioral sciences (Vol. 15, pp. 10109-10112). Retrieved from http://nbn-resolving.de/urn:nbn:de:bsz:352opus-56113

Iksan, M., \& Dirham, D. (2018). The Influence of the Economic Students' Motivations and Language Learning Strategies towards Their English Achievement in STIE Muhammadiyah Palopo. Ethical Lingua: Journal of Language Teaching and Literature, 5(1), 110-121. https://doi.org/10.30605/ethicallingua.v5i1.737

Kainta, E. (2016). The Use of Concrete Things as Media of Teaching to Improve Students'Vocabulary Achievement at MIS Azzikir Kalialia.

Llach, P.A. and Gomez, A.B. (2017). Children's Characteristic in Vocabulary Acquisition and use in the Written Production: Universidad de La Roja.

Losby, J., \& Wetmore, A. (2012, February). CDC Coffee Break: Using Likert Scales in Evaluation Survery Work. Natinonal Center for Chronic Diasese 
Preventetion and Health Promotion, 1-22. Retrieved from https://www.cdc.gov/dhdsp/pubs/docs/cb_february_14_2012.pdf

Marguerite Koons. (2013). Reading Is Easy or Ought To Be. Archway Publishing.

Meiliana, N. (2016). The Application of The Right Brain Methods: The Association and Correlation Method In Optimizing Vocabulary Mastery at The Seventh Grade Students of SMPN 1 Rancah-Ciamis. IOSR Journal of Economics and Finance, 1(1), 38-50. https://doi.org/https://doi.org/10.3929/ethz-b-000238666

Moghadam, S. H., Zainal, Z., \& Ghaderpour, M. (2012). A Review on the Important Role of Vocabulary Knowledge in Reading Comprehension Performance. Procedia - Social and Behavioral Sciences, 66, 555-563. https://doi.org/10.1016/j.sbspro.2012.11.300

Moya, G. I. (2013). Enhancing Motivation in Vocabulary Learning: A Cognitive Approach (Universitat Jaume I). Retrieved from http://repositori.uji.es/xmlui/bitstream/handle/10234/113460/TFM_2013_garcia I.pdf? sequence $=1$

Norbert, S. (2000). Vocabulary in Language Teaching. In R. C. Jack (Ed.), Cambrige University Press (Vol. 2). https://doi.org/10.1007/978-1-62703-254-4

Steinbrecht, A., \& Strausfeld, N. (2012). Letter from the Editors. Arthropod Structure and Development, 41(1), 1. https://doi.org/10.1016/j.asd.2011.11.002

Syae Purohman, P. (2011). Classroom Action Research Alternative Research Activity for Teachers. Retrieved from https://www.researchgate.net/publication/326083037\%0AClassroom

Thornburry, S. (2002). How to Teach Vocabulary. In S. Harmes (Ed.), Bluestone Press.

Umar, \& Irmayanti. (2017). Improving Students' Vocabulary Mastery by Using Authentic Materials through Communicative Approach. Ethical Lingua Journal of Language Teaching and Literature, 4(2), 151-164. Retrieved from http://journal.uncp.ac.id/index.php/ethicallingua/article/view/628\%0AAbstract

Waas, M. (2016) Motivating Students to Improve Vocabulary Mastery through Bingo Game at the $5^{\text {th }}$ Grade of SD Kristen Belakang Soya. 
17 | VISION: JOURNAL FOR LANGUAGE AND FOREIGN LANGUAGE LEARNING

Zohrabi, M. (2011). An Evaluation of Classroom Activities and Exercises in ELT Classroom for General Purposes Course. ERIC English Language Teaching, 4(1), 141-151. Retrieved from www.ccsenet.org/elt 